\title{
Predictors of correct interpretation of English and Bulgarian idioms by Russian speakers
}

\author{
Nataliya A. LAVROVA and Elena A. NIKULINA \\ Moscow Pedagogical State University \\ Moscow, Russia
}

\begin{abstract}
During intercultural communication, it is crucial to interpret correctly and to use appropriately foreign idioms which are culturally marked and reflect linguistic and cultural identity of a speech community. Interlocutors should be aware of the cultural and historical precedents that gave rise to the primary image underlying idiomatic expressions and thus created their unique phraseological worldview. The aim of the research is to find out what is a better predictor of correct idiom interpretation - degree of proficiency in a foreign language or degree of genealogical kinship between the native and foreign languages. The topicality of the research is justified by the need for a deeper understanding of linguistic and cultural identity of native and foreign-language speakers, with a view to facilitate and enhance cross-cultural communication. The working hypothesis is that due to the close genealogical kinship between Russian and Bulgarian and the users' advanced level of English, the number of correctly interpreted idioms may vary within a statistically significant medium range. The total sample comprises 5000 idioms (2500 English and 2500 Bulgarian ones). The subsample used in the experiment comprises 60 idioms (30 English and 30 Bulgarian ones) selected from 'The Oxford Dictionary of Idioms' and 'Nov fraseologichen rechnik na bylgarskiya jezik' ('Нов фразеологичен речник на българския език’) by means of stratified systematic sampling. The main methods used in the research include (1) comparative linguistic and cultural analyses, (2) scientific experimentation, (3) systematic and stratified sampling, and (4) a paired ttest. The experimental research and the paired t-test have proved our hypothesis and demonstrated that Russian participants correctly decode more Bulgarian than English idioms, with intergroup variation being statistically significant. Research findings have implications for cultural linguistics. Since translation loans (calques), isomorphic idioms, and idioms dating back to a common source are interpreted more quickly and more accurately than idioms which contain unique or culturallyloaded elements, such as old-fashioned words or proper names, access to cultural precedents that served as prototypes of set expressions contributes to a more seamless code-switching and enables communicants to penetrate deeper the mentality of a specific linguacultural community and thus become aware of the variability of cultural cognition and conceptualisation.
\end{abstract}

Keywords: idiom, typology, cultural linguistics, Bulgarian, code-switching, false friends of an interpreter, isomorphism

\section{For citation:}

Lavrova, Nataliya A. \& Elena A. Nikulina. 2020. Predictors of correct interpretation of English and Bulgarian idioms by Russian speakers. Russian Journal of Linguistics 24 (4). 831-857. DOI: $10.22363 / 2687-0088-2020-24-4-831-857$ 
Научная статья

\title{
Предикторы корректной интерпретации английских и болгарских идиом носителями русского языка
}

\author{
Н.А. ЛАВРОВА, Е.А. НИКУЛИНА \\ Московский педагогический государственный университет \\ Москва, Россия
}

\begin{abstract}
Аннотация
В процессе межкультурной коммуникации существует проблема корректной интерпретации и адекватного употребления иноязычных идиом, обладающих национально-культурной маркированностью и отражающих лингвокультурную идентичность определенного этноса. Коммуникантам необходимо владеть той культурно-исторической информацией, которая на определенном этапе развития языка послужила источником внутренней формы устойчивых выражений, создав уникальную языковую картину мира. Цель статьи - установить, который из двух факторов - близкое генетическое родство между родным и незнакомым иностранным языком или владение иностранным языком на высоком уровне - является более адекватным предиктором корректной интерпретации иноязычных идиом. Актуальность исследования обусловлена необходимостью более глубокого понимания лингвокультурной идентичности представителей разных лингвокультур с целью обеспечения максимально комфортного и эффективного межкультурного общения. Гипотеза исследования заключается в том, что, учитывая близкое генетическое родство между болгарским и русским языками, а также высокий уровень владения русскоязычными студентами английским языком, количество правильно декодируемых идиом в болгарском и английском языках может некоторым образом различаться, однако статистические расхождения в ту или другую сторону не превышают средний показатель. Общий объем выборки составил 5000 устойчивых выражений (2500 английских и 2500 болгарских идиом). Материал экспериментальной части исследования включает подкорпус из 60 устойчивых выражений (30 идиом из болгарского и 30 идиом из английского языка), отобранных с помощью стратифицированной систематической выборки из словаря 'The Oxford Dictionary of Idioms' и 'Нов фразеологичен речник на българския език’. В качестве основных методов исследования используются (1) метод сопоставительного лингвокультурологического анализа, (2) метод лингвистического эксперимента, (3) метод систематической и стратифицированной выборки, (4) метод статистической обработки t-test для парных выборок. Результаты исследования показали, что русскоязычные студенты, изучающие английский язык на продвинутом уровне, правильно декодируют больше болгарских, чем английских идиом, при этом межгрупповая вариативность статистически значима. Полученные данные имеют лингвокультурологическую значимость. Поскольку процент корректной интерпретации ка́лек, изоморфных идиом и идиом, восходящих к общему источнику, превышает процент правильно интерпретированных идиом, содержащих уникальные компоненты, как, например, устаревшие слова или имена собственные, представляется, что знание определенных культурных прецедентов, послуживших источником или прототипом устойчивых выражений, проливает свет на языковую картину мира, способствует более плавному переключению с одного языкового кода на другой, помогает понять особенности менталитета определенного лингвокультурного сообщества и гетерогенность культурной когниции и концептуализации.
\end{abstract}

Ключевые слова: идиома, типология, лингвокультурология, болгарский язык, переключение кодов, ложные друзья переводчика, изоморфизм 


\section{Для цитирования:}

Lavrova N.A., Nikulina E.A. Predictors of correct interpretation of English and Bulgarian idioms by Russian speakers. Russian Journal of Linguistics. 2020. Vol. 24. № 4. P. 831-857. DOI: $10.22363 / 2687-0088-2020-24-4-831-857$

\section{Introduction}

Phraseology is justly considered to be one of the most prolific areas of research, which explains why its systematic investigation started to gather momentum in the second half of the $20^{\text {th }}$ century. According to the most conservative estimates (Deignan 2005, Fiedler 2007), every fifth uttered expression is to a greater or lesser extent idiomatic. This suggests that speakers heavily rely on prefabricated items in conveying not only factual, but also evaluative and expressive information. Numerous terms referring to the subject-matter of the present research are used in theoretical literature on the topic. Unfortunately, however, there is no general agreement among scholars concerning the most optimal and adequate term, the word idiom being widely used in Western Europe and the USA, while phraseological unit is its preferable counterpart in Eastern Europe and Russia. In the present paper, no principal distinction is drawn between the terms idiom, idiomatic expression, set expression and phraseological unit, which are used interchangeably as their differentiation is not the priority of the research. However, the term idiom will be used by default because it is short, preferred in English, and is frequently used in research on phraseology.

Given that set expressions play a key role in efficient cross-cultural communication and contribute to a more seamless code-switching, the main aim of the research is to establish what is a better predictor of correct idiom interpretation degree of proficiency in a foreign language or degree of genealogical kinship between languages. To achieve this aim, we selected idioms from two distantly related languages - Bulgarian and English - and tested their interpretation by proficient or nearly proficient Russian speakers of English in an experimental format. The choice of Bulgarian is justified by its close etymological links to Russian, hence the presumption that students are unlikely to have much difficulty in interpreting Bulgarian idioms, as many of them are similar to Russian ones. However, students may have some difficulty interpreting English idioms because this lexical stratum is very challenging. Given this, students are likely to be under the influence of two diametrically opposed forces - centripetal (represented by the Bulgarian language) and centrifugal (represented by the English language), and it is the explicit aim of the present research to establish which one will take the upper hand.

As is well-known, Bulgarian and Russian are two closely related languages from the point of view of their genealogy: both belong to the Slavonic group of Indo-European languages, with Bulgarian belonging to its southern subgroup, and Russian belonging to its eastern subgroup. Both languages derive from the so-called Church Slavonic or the South Bulgarian variety of Slavonic languages, which was formed due to the missionary activities of Cyril and Methodius who originally 
introduced the Glagolitic script to different Slavonic peoples (Brown \& Ogilvie 2009). This alphabet was subsequently changed by the missionaries' disciples into Cyrillic named after one the missionaries who, contrary to the common belief, was not the inventor of the Cyrillic script. However, it was the Cyrillic script that ultimately caught on and spread on a vast territory stretching from the Mediterranean Sea to the Pacific Ocean (Keipert 2017).

Due to the languages' etymological kinship, a number of common grammatical, lexical, phonological and phraseological features can be found in Bulgarian and Russian. However, ever since the $10^{\text {th }}$ century, after Christianity and the Cyrillic alphabet spread in Russia and Bulgaria, centrifugal forces have overtaken the centripetal ones, and have largely shaped the linguistic typology of both languages (Vinogradov \& Dobychina 2018). The implication is that Bulgarian and Russian have mostly followed their own developmental paths (Ivanova 2019). This is partly due to extralinguistic factors, such as the lengthy dominance of Greeks and Turks in Bulgaria (Waugh 2019) which mostly affected lexis in the form of numerous borrowings: cf. $\mathrm{B}^{1}$. хора 'people', баджанак 'the husbands of both sisters', бояджия 'painter', тютюнджсия 'seller of tobacco', махала 'block of flats', yopan 'sock, stocking' (Kotova \& Janakijev 2001). Due to the impact of Greek on Bulgarian grammar, some of its verbal suffixes, namely -aca, -oca, -uca, -диса were borrowed to form the perfective aspect in Bulgarian: cf. брадясам 'to grow a beard', здрависам 'to congratulate' (Maslov 1981). Although the literary standard of Bulgarian was partly formed under the auspices of Russian classical literature (Polyvyannyy 2016), today words or structures considered to be old-fashioned in Bulgarian are neutral in Russian, while words or structures old-fashioned or moribund in Russian are frequently neutral designations of notions in Bulgarian, which represents the systemic relation between most of Bulgarian and Russian lexis: cf. B. очи 'eyes', рамо 'shoulder', уста 'mouth', риза 'shirt', крак 'leg' (neutral), нога 'leg' (old-fashioned), etc. (Brown \& Ogilvie 2009). As an example of centrifugal forces at play in Bulgarian grammar, let us consider the dative personal pronouns. While still in use in the $19^{\text {th }}$ century, the dative personal pronouns are moribund in Bulgarian, being supplanted by combinations of a preposition plus the accusative form of personal pronouns: cf. нему - на него, Вам - на Вас, нам - на нас, тям - на тях (Floria 2017).

Just like proto-Bulgarian, which was mostly analytic, modern Bulgarian is still classified by linguistic typology as analytic and at least partly isolating, with the notable exception of the ramified verbal paradigm: according to the most conservative estimates (Leafgren 2011), Bulgarian verbs can build up to 3000 forms, taking into account both regular and irregular formations as well as the potential presence of a thematic vowel which forms a bound stem of some tense forms (Zholobov 2016, Saenko 2017). Apart from the complicated system of verbal inflections, Bulgarian retains the distinction between absolute and relative tenses, which also held true for Old Russian, but has been lost in modern Russian

\footnotetext{
${ }^{1}$ Bulgarian.
} 
(Urmanchieva \& Plungian 2017). The small number of absolute tenses is a real stumbling block on the way to acquiring the knowledge of Bulgarian tenses by Russian and English speakers alike (Podtergera 2015), although since the same grammatical concept exists in English, its acquisition should progress faster for English speakers or for those who study English as a foreign or second language (Antipova \& Matveeva 2014). Unlike Russian and similar to English, Bulgarian is an article-retaining language. However, only definiteness is systematically expressed by means of the definite article called chlen ('member') in Bulgarian grammar. The definite article assumes a number of forms depending on the gender and number of nouns and on the syntactic position of a masculine noun in a sentence: момчето 'this boy', масата 'this table', куфаръm 'this coffer', градовете 'these towns' (Pashova 2005). A noteworthy feature of the Bulgarian definite article is that it can attach itself to the preceding adjective and even the possessive pronoun. In the latter case the grammatical concept of definiteness is expressed pleonastically (twice), which is not typical of most European languages: cf. В. моята стая (lit. 'the my room'), $\mathrm{E}^{2}$. my room, $\mathrm{G}^{3}$. mein Zimmer. Another grammatical idiosyncracity not shared by Bulgarian with Russian or English on a systematic level, though partly shared with French, is the so-called pronominal reprise: a pleonastic expression of an object (direct or indirect) or a subject by means of personal pronouns: Мене ми стана леко и хубаво lit. 'Me my felt well and good'. Дай ми ти на мене lit. 'Give me this for me' (Mitkovska, Bužarovska \& Ivanova 2017).

Due to the shared linguistic past, Bulgarian and Russian exhibit many more common features in grammar, lexis, phonology and phraseology, in contrast to English which shares few typological features with either Bulgarian or Russian (Vashcheva \& Koryakov 2018).

\section{Literature review}

According to Sharifian, "many features of human languages are entrenched or embedded in cultural conceptualisations" (Sharifian 2017: 21). The theoretical framework of cultural linguistics "proves a basis for understanding cultural conceptualisations and their realisation in language. Language plays a dual role in relation to cultural conceptualisation. On the one hand, linguistic interactions are crucial to the development of cultural conceptualisations, as they provide a space for speakers to construct and co-construct meanings about their experiences. On the other hand, many aspects of both language structure and language use draw on and reflect cultural conceptualisations" (Sharifian 2017: 24). One of the key concepts of cultural linguistics is cultural cognition which 'comes about as a result of social and linguistic interactions between individuals across time and space' (Sharifian 2017: 22).

\footnotetext{
${ }^{2}$ English.

${ }^{3}$ German.
} 
This section contains an analysis of works by authors who did comparative or typological research, including research into interpretation of idioms in several languages. In addition to the analysis of Bulgarian idioms (Todorova 2015), scholars discuss loan-translations into genealogically distant (Solano \& Kolarova 2015) and proximate languages (Dobrikova 2008). Some works are an attempt to compare whether it is proficiency or crosslinguistic links that determine a higher degree of idioms' interpretation, although the evidence is patchy and inconclusive (Chrissou 2018). A relatively high number of shared idioms in Slavonic languages, namely Polish, Ukrainian and Bulgarian, is explained by the common origin of those languages. However, the three languages are more likely to borrow words from the so-called 'upward' languages, primarily English, rather than from one another (Sosnowski, Blagoeva \& Tymoshuk 2018). The phenomenon of codeswitching in Internet forums is investigated by Todorova (2019) who sets out to prove that the insertion of English words and idioms into Bulgarian may also contribute to the common phraseological stock shared by culturally and linguistically distant languages. The investigation of semantic relations in the comparative phraseological units in English and Bulgarian (Holandi 2009) sheds some light onto the idioms shared by English and Bulgarian. The research by Cranmer (2017) focuses on intercultural communicative competence and on the challenges that it faces. The research by Bilá \& Ivanova (2020) focuses on the link between language, culture, and ideology. The paper by Nelyubova, Hiltbrunner \& Ershov (2019) investigates the reflection of Russian and French values in proverbs.

Todorova (2015) presents a formalized description of Bulgarian verbal idioms with the aim of studying their processing, i.e. recognition and interpretation in context. Giving a uniform description of 1,000 Bulgarian verbal idioms, the author focuses on their categorical, pragmatic, and grammatical information and proposes a method for formal representation of idioms in a morpho-syntactic dictionary which takes into account the idioms' paradigmatic and syntagmatic characteristics. Investigating the speed of their recognition both by native and non-native speakers, Todorova concludes that idioms are best recognized if they are homonymic with free phrases: cf.: vdigna glava ('to be proud/to raise one's head') with 6,737 occurrences; ostavyam na mira ('leave alone/ leave in peace') with 2,322 occurrences; treska trese nyakogo ('to have fever/ to be nervous') with 2,033 occurrences, and padna na kolene ('to beg/to fall on knees') with 1,526 occurrences in the corpus of the Bulgarian language. However, Todorova does not specifically study the factors that may facilitate the speed of recognition of Bulgarian idioms by speakers of related or unrelated languages, which is a limitation of her work.

Solano \& Kolarova (2015) devote their paper to the study of phraseological loan-translations in Bulgarian and French, which is a cross-linguistic and crosscultural study and which aims, among other things, to highlight the factors that facilitate idiom recognition by speakers of two distantly related languages. The conclusion the scholars draw from their research is that loan-translations are more 
frequent from French into Bulgarian, and hence Bulgarian learners of French are more likely to recognize related idioms in French by virtue of their having comparable idioms in Bulgarian. In most cases, French learners of Bulgarian are not greatly helped by the few idiomatic calques in Bulgarian because the bulk of Bulgarian idioms is Slavonic and differs dramatically from French both typologically and etymologically. Both groups of learners, however, have approximately the same advantage when faced with the so-called Anglicisms isomorphic English calques in both Bulgarian and French: $\mathrm{cf}^{-\mathrm{Fr}^{4}}$. franchir la ligne rouge and B. пресичам червената линия (Е. 'to cross the red line'), Fr. être sur le même bateau and В. в една и съща лодка сме (Е. 'to be in the same boat') or Fr. Au milieu de nulle part and B. в средата на нищото (E. 'in the middle of nowhere'). There are also instances of language-specific calques, such as B. имам nеперуди в стомаха (E. 'to have butterflies in the stomach') and слон в стаята (E. 'an elephant in the room') or Fr. ce n'est pas ma tasse de thé (E. 'it's not my cup of tea') and été indien (E. 'Indian summer'). Apparently, the interpretative advantage belongs to the speakers of languages in which there are language-specific calques. Thus, a speaker of Bulgarian who is learning English is more likely to decode the English idiom an elephant in the room, while a speaker of French who is studying English is more likely to correctly interpret the idiom Indian summer. It could also be hypothesized that, all else being equal, speakers of English and French are more likely to be familiar with idioms from their respective languages for two extralinguistic reasons. First, historically, a lot of borrowings into English from Norman French occurred in the centuries following the Norman Conquest. Second, there is more cultural and linguistic crosspollination between French and English than between French/English and Bulgarian. Apart from that, Bulgarian is part of the Balkan Spachbund, while French, English and other European languages constitute what Stepanov calls 'the European Sprachbund', i.e. a linguistic union with a number of shared features that exist in all or nearly all of the European languages (Stepanov 2016).

One of the channels through which Bulgarian may experience an influence from English is Internet forums where code-switching and 'interlanguage' are likely to emerge due to the egalitarian, informal mode of communication. Todorova (2019) studies the influence that English has on the Bulgarian forum 'Netspeak' for Bulgarian women living in the USA. The investigated forum discussions include 52,020 lexical items, of which around $2 \%$ are nouns borrowed from English due to their easy grammatical adaptation. While verbs are rarely borrowed because of their divergent typological structures in English and Bulgarian, ready-made constructions, idioms and phrasal verbs are adopted, adapted and assimilated into Bulgarian more readily. Although the speed and quality of the interpretation of idioms is not directly tested in the research, the author indicates that the potential speed and degree of accuracy may be higher for those Bulgarian users of the forum Netspeak in the USA who have been exposed to the English language either through

\footnotetext{
${ }^{4}$ French.
} 
the participation of other, possibly English speaking users, or through the involuntary incorporation of Anglicisms in the speech of Bulgarian co-users of the forum. This hypothesis suggests that the degree of familiarity with a foreign language, even if this language is not explicitly studied, may positively correlate with the correct interpretation of idioms in this foreign language.

The research by Cranmer (2017) focuses on intercultural communicative competence and on numerous challenges that stand in the way to acquiring it. Apart from different communicative styles, some of the impediments on the way to intercultural competence are etymologically linked words in two or more related languages that often lead communicators up the garden path by urging them to form associations with concepts that have no bearing on the meaning of the word in another language. In connection with Bulgarian and Russian, this pertains to the pair of words вестник ('newspaper' in Bulgarian) - вестник ('academic journal' in Russian). These words completely overlap in their form and are only very distantly related in their current meaning.

The research by Bilá \& Ivanova (2020) focuses on the inherent link between language, culture, and ideology, and emphasizes that "in the network of the relationships between humans, language and culture, humans are defined as biological, social, and cultural beings with all these aspects closely bound together and constituting a single integral, inseparable package' (Bilá \& Ivanova 2020: 221). This means that social and cultural practice is volens nolens reflected in language.

The paper by Nelyubova, Hiltbrunner \& Ershov (2019) investigates the reflection of Russian and French basic values in proverbs. Based on the fact that each nation has a certain hierarchically organized set of values, which only partly coincide with other cultures, the authors believe that it is important to identify both their universal and culture-specific features. According to the researchers' hypothesis, the thematic classification of proverbs may directly or indirectly reveal the values of a particular nation, and the quantitative correlation of proverbs related thematically illustrates this hierarchy of values: "a bigger or smaller number of proverbs on a certain topic indicates the degree of their importance in the consciousness of native speakers of a corresponding linguistic community" (Nelyubova, Hiltbrunner \& Ershov 2019: 224). The method of linguistic and axiological analysis used by the researchers and the findings of the research suggest that language reflects the most salient cultural concepts which may be rather dissimilar across cultures: while advice, trouble, love, hole and expectation are linguistically, culturally and conceptually salient for Russian speakers, animals, exchange, daily routine and religion are, apparently, some of the key cultural concepts for the French.

In his research, Chrissou (2018) proceeds from the premise that there is a broad agreement in phraseological research upon the fact that collocational fluency is a significant determinant of efficient cross-cultural communication. For this reason, high frequency and common set phrases with a high relevance in written and oral communication should be subject to systematic cross-linguistic analysis. Applying 
the methods of contrastive linguistics, the study postulates that linguistic proximity has a positive impact on cross-cultural communication and code-switching, reducing the communicative burden, whereas lack of proximity is assumed to increase the degree of difficulty. However, there is still inconclusive evidence about whether it is the formal, semantic or etymological congruency of two different languages that plays the key role in facilitating code-switching. The findings by Chrissou testify to the fact that the degree of proficiency in a foreign language is a facilitating factor in cross-cultural communication when idioms are from two or more languages that are very distant relatives. When languages are related more closely, however, it is their inherent properties that determine the difficulty degree for code-switching. However, no relying criteria for measuring the degree of distance between two languages are suggested; nor is a third language involved, for example another language from the Germanic group, such as Dutch, Swedish or Norwegian, in order to corroborate the hypothesis that linguistic proximity is a facilitating factor in the interpretation of idioms.

Columbus (2013) is primarily interested in the types of idiomatic structures that exist and that should be selected by experimental researchers as a sample for the study. According to Columbus' findings, most scholars select a biased sample of idioms by virtue of having their own, sometimes idiosyncratic, sometimes frankly skewed understanding of what constitutes an idiom. To obtain valid and reliable data, it is imperative to incorporate in a study an approximately equal measure of all the three main types of idiomatic expressions, namely restricted collocations, idioms, and lexical bundles. These subtypes of set expressions should be singled out using corpus-based measures and human ratings. The study empirically validates these categories as described by certain phraseologists in the European tradition, which is accomplished using various multi-word expressions from the British National Corpus, from across the continuum of frequent to infrequent occurrences and co-occurrences. As a conclusive warning, Columbus recommends selecting the final sample through the method of systematic or random sampling, which ensures bias-free, objective and experiment-worthy idiomatic expressions.

The research by Szerszunowicz (2013) discusses the phenomenon of exponential growth of idioms in some Slavonic languages, with Polish as the primary focus of investigation. The author claims that following major political, social and/or economic upheavals, an upsurge of set expressions can be observed in a linguacultural community. In the decades after the disintegration of the Soviet Union, this phenomenon primarily concerns former Soviet countries or countries that were subject to the Soviet influence, among which Bulgaria is no exception. According to Szerszunowicz, the major source of new idiomatic expressions is a foreign language or a foreign culture which is considered to be economically, politically, and socially more stable and prestigious and is typically looked upon as a source of inspiration for coining new idioms. English-speaking countries have arguably been at the forefront of political, economic and social changes, they are 
typically considered egalitarian societies, not set against either human or linguistic migration, hence the relatively free cross-pollination between English-speaking countries and their close and distant neighbours. The result of such egalitarian policy, however, is frequently one-sided: while many Slavonic languages extensively borrow from English, English lags behind, due to the lack of an objective need to fill in either nominative or expressive lacunae. This results in more loan-translations in Slavonic languages, such as Bulgarian, and hardly any calques from Slavonic languages into English. On the plus side of this one-way process is that speakers of English and Bulgarian can recognize those Bulgarian idioms that have been loan translated from English.

The research by Sosnowski, Blagoeva, \& Tymoshuk (2018) examines phraseological innovations in Bulgarian, Polish and Ukrainian. Particular attention is paid to trends in the development of phraseology and to the sources of the enrichment of the phraseology of the three studied languages. The main finding of the research is that the degree of linguistic proximity correlates positively with the level of recognition and correct interpretation of foreign-language idioms. Since Bulgarian, Polish and Ukrainian are closely related Slavonic languages, the core of common idiomatic word-stock can be singled out, which is rather extensive and is mutually comprehensible to speakers of the three languages. Despite the valuable heuristics of the research, the authors fail to compare closely related languages with a distantly related language in order to obtain objectively quantifiable data with respect to what is more weighty in determining the degree of correct idioms' interpretation: the etymological proximity of two or more languages or the degree of learners' proficiency in a foreign language. This is the research question the present study addresses, thereby filling in the existing research gap.

Dobrikova (2008) is an in-depth study of both theoretical and practical aspects of comparative phraseology. The idiomatic word-stock from the two closely related languages (Slovak and Bulgarian) is studied and the conclusion is reached that there is a lot of cross-over and cross-pollination between the phraseologies of the two languages. However, much depends on the theoretical framework within which scholars of phraseology work: while Slavonic scholars mostly follow the phraseological paradigm adopted by Soviet linguists, Bulgarian phraseologists embrace a more modest and limited view of what constitutes idiomatic language and primarily regard only lexical set expressions with a completely transferred meaning as truly idiomatic, whereas others are treated as marginal or engendered by common rules of syntactic derivation. Admitting that the etymological proximity of languages certainly correlates positively with the degree of correct idioms' interpretation, the scholar concedes that non-systematic analysis of very closely related and distantly related languages was carried out and the degree of proficiency in a foreign language versus the degree of linguistic relatedness was not analyzed with respect to its influence on idioms' interpretation.

Finally, the in-depth study by Holandi (2009) investigates semantic relations in comparative idioms in English and Bulgarian. These are set expressions that 
contain conjunctions as or like (като) in their structure (as good as gold, плашлив като заек lit. 'fearful like a hare'). Having investigated 6 semantic groups of Bulgarian and English idioms, the author draws the following conclusion. On balance, the ease of the interpretation of idioms by either Bulgarian or English native speakers depends on the number of shared idiomatic word-stock. This common word-stock is determined by the three main factors, all of which are extralinguistic in nature. First, the so-called animalisms (or zoomorphic idioms) reveal a lot of commonality in terms of structure and meaning, which is explained by the comparable symbolic associations ascribed to most animals, such as hares, wolves, foxes, dogs, etc. The second group of Bulgarian-English idioms which is also relatively easily interpreted by speakers of Bulgarian and English is constituted by religious idioms due to the fact that most of them derive from the Bible, and since both Britons and Bulgarians are Christians, it is only natural to expect them to have shared comparable values which get reflected in the idiomatic language. Finally, there is another group of easily interpreted idioms, namely, translationloans from English into Bulgarian. However, this is the least numerous group (10\%, compared to the other two), since loan-translation is a relatively inconspicuous process in modern Bulgarian, although, as other researchers have observed (see above), it cannot be dismissed out of hand. Echoing the other scholars mentioned above, Holandi discusses and contrasts two distantly related languages, whose phraseology can mostly be compared from the typological, but not genealogical point of view and whose commonality, therefore, is mostly determined by extralinguistic and cultural factors, such as borrowings from the same source and humans' common cognitive make-up. Table 1 sums up the same or similar Bulgarian and English idioms.

Table 1

The main groups of structurally and semantically comparable Bulgarian and English idioms (after Holandi 2009)

\begin{tabular}{|c|c|c|}
\hline $\begin{array}{l}\text { The same zoomorphic idioms } \\
\text { in English and Bulgarian }\end{array}$ & \begin{tabular}{|c|} 
The same/similar phytonymic \\
idioms in English and Bulgarian
\end{tabular} & $\begin{array}{l}\text { The same biblical idioms } \\
\text { in English and Bulgarian }\end{array}$ \\
\hline $\begin{array}{l}\text { as timid as a hare } \\
\text { плашлив като заек }\end{array}$ & \begin{tabular}{|l|} 
stick like a burr \\
закачам се като шипка
\end{tabular} & $\begin{array}{l}\text { as old as Methuselah } \\
\text { стар като Meфасуил }\end{array}$ \\
\hline $\begin{array}{l}\text { as scared as a rabbit } \\
\text { страхлив като заек }\end{array}$ & $\begin{array}{l}\text { quake/quiver/shake/tremble like } \\
\text { an (aspen) leaf } \\
\text { треперя като лист }\end{array}$ & $\begin{array}{l}\text { as sure as death } \\
\text { грозен като смъртта }\end{array}$ \\
\hline $\begin{array}{l}\text { breed like rabbits } \\
\text { плодим се като зайци }\end{array}$ & \begin{tabular}{|l|} 
grow/spring up like mushrooms \\
растат като гъби (след дъжд)
\end{tabular} & $\begin{array}{l}\text { as poor as Job } \\
\text { беден като Йов }\end{array}$ \\
\hline \multirow[t]{2}{*}{$\begin{array}{l}\text { run like a hare / rabbit } \\
\text { бягам като (изтърван, } \\
\text { пушнат) заек }\end{array}$} & & $\begin{array}{l}\text { as still as death (or as the grave) } \\
\text { тих като смъртта }\end{array}$ \\
\hline & & $\begin{array}{l}\text { as proud as Lucifer } \\
\text { хитьр като дявол } \\
\text { as black as hell } \\
\text { черен като дявол }\end{array}$ \\
\hline
\end{tabular}




\section{Typological analysis of Bulgarian, Russian and English idioms}

The Bulgarian proverb Куче което лае не хапе lit. 'A dog that barks does not bite' has the following English and Russian equivalents: Собака, которая лает, не кусает lit. 'A dog that barks does not bite'; to be all bark and no bite. A barking dog seldom bites. In terms of the structure and meaning of the expression, we observe that, first, in English there are (at least) two expressions with a similar image and meaning; second, in both Russian and Bulgarian the proverbs are more generalizing than in English: the inclusion of the adverb of degree seldom (A barking dog seldom bites) makes the claim about the behaviour of dogs less categorical. The concept of being wishy-washy, lacking reserve, stamina or determination is expressed by idioms with comparable images in the three languages: cf. В. ни риба, ни рак lit. 'neither fish, nor crayfish'; $\mathrm{R}^{5}$. ни рыба, ни мясо lit. 'neither fish, nor meat'; E. neither fish nor fowl. What is of note is that in Bulgarian and English the principle of consonance operates, which, apparently, explains the choice of the structural elements: apart from expressing a similar concept, they begin with the same consonant. In Russian, a slightly different strategy is employed: fish and meat belong to the thematic group of nourishing food, and the words 'fish' and 'meat' stand in complementary relations to each other as co-hyponyms. They are also contrasted in that most people prefer either fish or meat and there are some who, for reasons of health, may choose to eat fish, but not meat. The Bulgarian idiom като изтискан лимон lit. 'like a squeezed lemon' has a close counterpart in Russian: cf. как выжатый лимон lit. 'like a squeezed lemon', while there is no idiom with a comparable image in English: cf. on my last legs, dog-tired, to feel as if death warmed up this morning, etc. The concept of close psychological resemblance between relatives is expressed by similar idioms in Bulgarian and Russian: cf. В. Крушата не пада по-далеч от дървето lit. 'A pear does not fall far from the tree'. R. Яблоко от яблони (не далеко падает) lit. 'An apple does not fall far from the tree'. In English, a different image underlies a comparable idiom: a chip off the old block. Two idioms with the same image also exist in English - one predicative (a proverb), the other one - its shortened, non-predicative variant: The apple does not fall far from the tree/(not) far from the tree. A more prototypical, Biblical fruit was chosen as the basis of the Russian and English proverbs, while a less prototypical one, although still common, underlies the Bulgarian idiom (Mokienko 2017).

A similar underlying image exists in the following idioms from all the three languages: cf. В. дишам във врата на някого lit. 'to breathe on smb.'s neck', R. dышать в спину lit. 'to breathe onto smb.'s back', E. to breathe down smb. 's neck. However, in terms of meaning, only the Bulgarian and English idioms are similar, while in Russian the idiom has the meaning of closely following someone with the intention of metaphorically overtaking them or closely watching their actions. The Russian equivalent of Bulgarian and British idioms is стоять над

\footnotetext{
${ }^{5}$ Russian.
} 
душой lit. 'to stand above smb.'s soul'. The Bulgarian idiom обръщам гръб lit. 'to turn one's back' has comparable counterparts in Russian and English: повернуться спиной lit. 'to turn one's back', to turn one's back. However, only the Bulgarian idiom can be followed by both animate and inanimate objects, while Russian and English idioms are typically followed by names of animate objects. As a result, the Bulgarian idiom has the meaning of 'to turn over a new leaf' (Sabeva \& Zagorova 2015), while English and Russian idioms have the meaning of leaving somebody in the lurch. Similar images underlie the idioms B. точа си зъбите lit. 'to cut one's teeth', R. точить зуб lit. 'to cut one's tooth', E. to cut one's teeth on smth. However, all the three idioms have different meanings and can thus be considered as false friends: 'to eagerly anticipate smth.' (in Bulgarian), 'to get experience in some sphere' (in English), and 'to bear a grudge against smb. in preparation for revenge' (in Russian).

The Bulgarian idiom влизам под кожата на някого lit. 'to get under smb.'s skin' differs in its meaning from the English idiom with a similar image to get under smb. 's skin 'to irritate smb.'. Here the underlying image, which was originally the same, engendered two different implications that turned into systematic meanings. One implication of 'getting under smb.'s skin' is that it may cause unpleasant physical sensations, such as itch or pain. Another implication is that someone is getting so intimately close that you feel warmth and care and hence some pleasant physical sensation. The Bulgarian idiom излизам из кожата си lit. 'to get out of one's skin' corresponds to the English expression to get out of one's way to do smth.. The Russian counterpart with a comparable underlying image лезть из кожи вон lit. 'to get outside one's skin' is a false friend with the meaning 'to make an utmost effort to achieve smth'. The concept of despair is conveyed by somatic idioms in the three languages: cf. В. клюмвам нос lit. 'to peck with one's nose', R. nовесить голову lit. 'to hang down one's head', E. to be down in the mouth (or to walk with drooping shoulders). The Russian idiom клевать носом lit. 'to peck with one's nose' has the meaning of feeling sleepy. All the three idioms have the underlying metonymical basis from which different implications were drawn by different linguistic communities. When your nose or head or shoulders are down, it is usually due to some physical or psychological malaise which presses the body down. The down posture may also mean that one is physically tired and is seeking a horizontal position, or one is psychologically overwhelmed and has little stamina left to walk upright. The idea of wishing somebody good luck or deeply caring for someone's well-being is expressed by the idiom стискам палии lit. 'to squeeze one's fingers' in Bulgarian, кулаки держать за к-л lit. 'to hold one's fists for smb.' in Russian and to keep one's fingers crossed in English. The difference between the idioms is down to the different images engendered by the words 'fist' ('кулак') in Russian, 'fingers' in English and squeezing one's fingers in Bulgarian. Apart from that, the English idiom reflects an old superstition, thus providing additional cultural information (Kuiper 2013).

Drastically different images are employed for the expression of the idea of an impossible occurrence in the future, of the crushing of hopes: cf. B. когаmo 
си видиш ушите без огледало, R. когда рак на горе свиснет, Е. when two Sundays come together. This idea is expressed with the help of an absurd image in all the three languages, although the 'absurdity' is in each case different: the literal gloss of the Bulgarian proverb is 'when you see your ears without a mirror', the Russian gloss is 'when a crab whistles on a mountain', and the image behind the English saying is the wishful state of affairs when one Sunday is directly followed by another. Interestingly and in contrast to Russian, the idea of a private, one-toone conversation and the idea of being very careful, vigilant and watchful is expressed emphatically and hyperbolically in Bulgarian by means of the expression четири очи lit. 'four eyes': cf. B. на четири очи lit. 'on four eyes', R. сглазу на глаз lit. 'an eye with an eye', Е. tete-a-tete, В. отварям си очите на четири lit. 'open all the four of your eyes', R. глядеть/смотреть в оба lit. 'to look with both (of your eyes)', E. to keep one's eyes peeled. The idea of deceiving or misleading someone is expressed through similar Bulgarian and English idioms: В. хвърлям npax в очите lit. 'to throw dust in the eyes', E. to throw dust in smb. 's eyes. The Russian idiom, however, is somewhat of a false friend, as the expression пускать пыль в глаза lit. 'to let dust in the eyes' has the additional semantic twist of presenting a better image of oneself (Gurevich \& Dozorets 1988, Baranov \& Dobrovol'skij 2014).

The concept of something that has both positive and negative consequences is expressed by the following idioms in the three languages: cf. В. нож с две остриета lit. 'a knife with two edges', R. палка о двух конщах lit. 'a stick with two ends', обоюдоострый меч lit. 'a double-edged sword', E. a double-edged sword. The difference in the motivation of the respective idioms is threefold. First, the image of a knife corresponds to the image of a sword in Russian and English; second, in Russian there are two idioms to express the same idea, and third, the idiom обоюдоострый меч is less frequent than its English and Bulgarian counterparts and is more formal than its more frequent Russian synonym палка $о$ двух концах.

Another typologically relevant, though not very frequent group of idioms in Bulgarian includes those that have similar underlying images and may therefore be mistaken for interchangeable, synonymous idioms. However, their meanings are different, and sometimes dramatically so. As an example, consider the two predicative Bulgarian idioms: cf. Каквото му е на сърието, това му на езика lit. 'What he has on the heart, he has on the tongue'. Каквото ми е на душата, това ми на ycmama lit. 'What I have on the soul, I have on the mouth'. The first idiom has the meaning 'to be sincere and open-hearted'. The second idiom means 'to speak one's mind', 'not to mince words', 'to speak what you really think'. Compared to the Russian idiom with a similar image, Что на уме, то и на языке lit. 'What is on the mind, the same is on the tongue', the difference in the evaluative connotation emerges: the Russian idiom has negative connotations and refers to a person who is not very intelligent and cannot keep a secret or who says silly things. None of the idioms has a set expression with a comparable image in English, with 
a relative exception of the first Bulgarian idiom, which can be translated into English as 'to wear one's heart upon one's sleeve', a well-known Shakespearism.

There is also a group of idioms, mainly in Bulgarian and Russian, in which a full image in one language corresponds to a curtailed image in the other, as in the case of the following idioms: В. върви по мед и масло lit. 'It goes like on honey and butter', R. идет как по маслу lit. 'It goes like on butter'. As can be seen, the Bulgarian idiom contains an extra image of honey absent from the Russian idiom, which partly explains why some native Russian speakers (personal communication) associate the idiom with a lubricant, i.e. a non-edible substance. In English, a completely different image underlies the same idea - that of an efficient mechanism: cf. to run like clockwork. The Bulgarian idiom om друго mесто съм lit. 'I am made from different dough' has an isomorphic Russian idiom из другого mecma lit. 'from different dough'. The closet English equivalent is 'a horse of a different colour' (Sabeva \& Zagorova 2015). However, the meaningful difference between the three idioms is that Bulgarian and Russian ones refer to an animate entity, while the English idiom refers to an inanimate, abstract notion, such as the subject matter under discussion regarded as partly or completely inappropriate.

In terms of the synonymic usage of numbers, it has to be observed that number 3 is more often used in the structure of Bulgarian and Russian idioms, while number 9 plays a more prominent role in the English language. On the whole, however, number 3 is more frequent in Bulgarian. This could probably be explained by the Orthodox religion shared by Russians and Bulgarians, and a different religious paradigm in English-speaking countries: В. всяко чудо за три дни lit. 'Any wonder (lasts) for three days'. E. A nine days' wonder. R. Бог mpouиy любит lit. 'God loves (The Holy) Trinity'. The allomorphic character of the Bulgarian proverb Три пъти мери, веднъж режи lit. 'Measure three times, cut only once' and its Russian counterpart Семь раз отмерь, один раз отрежь lit. 'Measure seven times, cut only once' is down to two factors: a fewer number of times corresponds to a greater number in Russian, which testifies to a more prominent role played by number 3 in Bulgarian; second, only the Bulgarian proverb is based on assonance and rhyme, which means that the valuer of the two proverbs is slightly different in Russian and Bulgarian. The French term valeur was introduced by F. de Saussure to refer to non-semantic, conceptual or paradigmatic differences between linguistic signs (words or phrases) that otherwise may be considered as translational equivalents. This means that although the Bulgarian proverb Три пъти мери, веднъж режи and its exact translational equivalent in Russian Семь раз отмерь, один раз отрежь are semantically complete matches, there are additional, conceptual differences between them due to different numerals and the presence of rhyme in the Bulgarian proverb.

Sometimes all the three (predicative) idioms have the same source (the Bible, fables, etc.) and yet develop slightly different meanings due to the different paths they follow through the centuries. This pertains to the well-known saying traced back to Aesop's fable about the profligate youth who sells out everything down to 
his last coat when he spots a swallow and thinks that it is going to be warm soon and so he does not need a coat. Observing that the Bulgarian and English sayings can be regarded as false friends, Sabeva \& Zagorova (2015) differentiate between the meanings of the two in the following way: 'In English the proverb one swallow doesn't make a summer/spring is used only in reference to situations, and not to people. The saying means that because one good thing has happened, one cannot assume that more good things will happen in the future or that the whole situation will improve' (Sabeva \& Zagorova 2015: 65).

Table 2 sums up some major typological cross-linguistic relations between Bulgarian, English and Russian idiomatic expressions. The marker vs ('versus') separates idioms which are contrasted to each other. For example, in the second column the first two proverbs (Russian and Bulgarian) are separated from the English one by this marker, which means that the Russian and Bulgarian proverbs are contrasted with the English one. Naturally, the first column in the table does not have the marker 'vs', since all the idioms are identical from the point of view of their meaning and structure. The fourth column does not have this marker either, as the idioms are considered as nearly identical equivalents on account of a close underlying image and the identical meaning in all the three languages.

Table 2

Typological classification of Bulgarian, Russian and English idioms

\begin{tabular}{|c|c|c|c|}
\hline $\begin{array}{l}\text { The same image } \\
\text { and meaning } \\
\text { (in two or three } \\
\text { languages) }\end{array}$ & $\begin{array}{l}\text { The same image, } \\
\text { different meanings } \\
\text { (in two or three } \\
\text { languages, } \\
\text { false friends) }\end{array}$ & $\begin{array}{l}\text { Different images, } \\
\text { the same meaning } \\
\text { (in two or three } \\
\text { languages) }\end{array}$ & $\begin{array}{c}\text { Comparable (similar) } \\
\text { images and meanings } \\
\text { (in two or three } \\
\text { languages) }\end{array}$ \\
\hline $\begin{array}{l}\text { като изтискан лимон } \\
\text { как выжатый лимон }\end{array}$ & $\begin{array}{l}\text { One swallow does not } \\
\text { make a summer } \\
\text { vs Една лястовица } \\
\text { пролет не прави }\end{array}$ & $\begin{array}{l}\text { Крушата не пада по- } \\
\text { далеч от дървето } \\
\text { яблоко от яблони } \\
\text { vs a chip off the old } \\
\text { block }\end{array}$ & $\begin{array}{l}\text { ни риба, ни рак, } \\
\text { ни рыба, ни мясо, } \\
\text { neither fish nor fowl }\end{array}$ \\
\hline $\begin{array}{l}\text { дишам във врата на } \\
\text { някого } \\
\text { to breathe down smb.'s } \\
\text { neck. }\end{array}$ & $\begin{array}{l}\text { дишам във врата на } \\
\text { някого } \\
\text { to breathe down smb.'s } \\
\text { neck. } \\
\text { vs дышать в спину }\end{array}$ & $\begin{array}{l}\text { върви по мед и масло } \\
\text { vs to run like clockwork }\end{array}$ & $\begin{array}{l}\text { върви по мед и масло } \\
\text { идет как по маслу }\end{array}$ \\
\hline $\begin{array}{l}\text { Яблоко от яблони The } \\
\text { apple does not fall far } \\
\text { from the tree }\end{array}$ & $\begin{array}{l}\text { точа си зъбите } \\
\text { vs точить зуб } \\
\text { vs to cut one's teeth on } \\
\text { smth. }\end{array}$ & & $\begin{array}{l}\text { всяко чудо за три дни } \\
\text { a nine days' wonder. }\end{array}$ \\
\hline $\begin{array}{l}\text { обоюдоострый меч } \\
\text { a double-edged sword }\end{array}$ & $\begin{array}{l}\text { излизам из кожата си } \\
\text { vs лезть из кожи вон }\end{array}$ & & \\
\hline $\begin{array}{l}\text { хвърлям прах в очите } \\
\text { to throw dust in smb.'s } \\
\text { eyes. }\end{array}$ & & & \\
\hline
\end{tabular}




\section{Hypothesis, methods, materials and data collection}

\subsection{Research hypothesis}

Bulgarian is so closely related to Russian that seeing Bulgarian words on a printed page, one is bound to immediately notice a lot of crossover between letters, morphemes, syntactic structures and set expressions. Unlike Bulgarian, English is much further removed from Russian etymologically, although all the three languages belong to the Indo-European family. Given this, the working hypothesis of the present research is that nearly-proficient Russian students of English are exposed to centripetal and centrifugal linguistic forces that may cause them to produce a (slightly) bigger number of either Bulgarian or English idioms, with the postulated statistical variation lying within the medium range.

\subsection{Participants}

The participants that took part in the research are 50 Russian speakers of English of comparable age, socio-economic status and educational level: third-yearstudents from Moscow Pedagogical State University, aged 20-22, with advanced level of English. All the students completed the course in English lexicology, of which English phraseology forms a substantial part, totaling around 40 academic hours. All the participants also completed a course of general linguistics during their 1 st academic year, in which, among other aspects of general linguistics, they studied the genealogical classification of languages. This module accounts for around 35 academic hours and comprises rather detailed information about the Slavonic, Germanic, Romance and other groups of Indo-European languages. Special attention was paid to the Slavonic and Germanic languages because most of the students are Russian and their major is English. Given this, the participants are familiar with the general typology and genealogy of Bulgarian, although none of them knows Bulgarian to any degree of proficiency.

\subsection{Materials}

The material for the research consists of two parts: the total sample includes 5000 idioms - 2500 from English and 2500 from Bulgarian. The equal numbers of idioms were chosen for reasons of quantitative objectivity and validity. The final subsample, which was used in the experimental part of the research, comprises 60 idioms (30 Bulgarian and 30 English ones) selected from 'The Oxford Dictionary of Idioms' (2004) and 'Nov fraseologichen rechnik na bylgarskiya jezik ('Нов фразеологичен речник на българския език' 1999) compiled by means of stratified systematic sampling: selecting every tenth example on a page with a new alphabet letter. This method ensures the reliability and impartiality of the final sample. The number of idioms was determined by the assumption that 30 is the minimum required number for a t-test to be considered statistically relevant and representative. Choosing more idioms would have put undue stress on students who were given only 90 minutes to complete the task. Since the assignment ('Supply the 
meaning of each English and Bulgarian idiom without consulting a dictionary') is open-ended, it required a considerable amount of time. Asking the students to interpret more idioms would have compromised the accuracy of the experiment.

\subsection{Procedure and data analysis}

All the students were presented with two lists of 30 idioms and given 90 minutes to complete the two tasks. Each idiomatic expression was thus given slightly more than a minute, which is enough time to produce the target item if the learner is aware if its existence or can guess its meaning from its constituent parts. In addition to the explanation of the task, an example of its possible completion was provided. An unstructured, post-hoc interview was conducted with the participants to find out what difficulties they had experienced when completing the task. Table 3 is a faithful reproduction of the task presented to the participants. As can be seen from Table 3, the task was given in English, since all the participants are advanced or proficient speakers of English.

Table 3

The experimental task given to the participants

In the table below, there are $\mathbf{3 0}$ idioms from English and $\mathbf{3 0}$ idioms from Bulgarian, which are unrelated in their meaning or structure. Please, supply the meaning of each English and Bulgarian idiom without consulting a dictionary. Make a guess if you are unsure of an idiom's meaning. Answers can be given either in English or in Russian. You are given $\mathbf{9 0}$ minutes to accomplish the task.

Example: to have green fingers: to enjoy working in the garden.

хвърлям прах на някого: пускать пыль в глаза, to throw dust in smb.'s eyes

\begin{tabular}{|l|l|}
\hline In Abraham's bosom: & хващат ме дяволите: \\
\hline a bad quarter of an hour: & ихзвърлям и бебето с мръсната вода: \\
\hline to carry the can: & морете ми е до колене: \\
\hline a damp squib: & приличат си като две капки вода: \\
\hline to have someone eating out of your hand: & гръм от ясно небе: \\
\hline a false dawn: & падам от небето: \\
\hline garbage in, garbage out: & правя кал: \\
\hline all hands: & отварям си очите на четири: \\
\hline to be in for smth.: & огън ми гори на главата: \\
\hline in jig time: & гладен съм като волк: \\
\hline to make a killing: & да си оближеш пръстите: \\
\hline a blot on the landscape: & като куче и котка: \\
\hline to meet one's maker: & мечешка услуга: \\
\hline
\end{tabular}




\begin{tabular}{|l|l|}
\hline call of nature: & повтарям като папагал: \\
\hline good offices: & с един куршум два заека: \\
\hline another pair of shoes: & ходя като муха без глава: \\
\hline quick and dirty: & на краставичар краставици продавам: \\
\hline at the end of the rainbow: & сгазвам лука: \\
\hline in the last chance saloon: & завъртам главата на някого: \\
\hline herein lies a tale: & не мога да си вдигна глават от работа: \\
\hline it is all up with: & слагам си главата в торбата: \\
\hline to take a dim view of: & затънал съм до гуша в дългове: \\
\hline between you and me and the wall: & стъпвам на врата на някого: \\
\hline give it large: & изплезвам език: \\
\hline plain Jane: & имам зъб на някого: \\
\hline the icing on the cake: & като опре ножа до кокала: \\
\hline in one ear and out the other: & кракът ми няма да стьпи тук: \\
\hline as game as Ned Kelly: & протягам си краката според чергата: \\
\hline you can't keep a good man down: & намд пи-далече от носа си: \\
\hline to drop names: & вит: \\
\hline
\end{tabular}

The interpretation of results was conducted with the help of the paired t-test. This statistical tool is appropriate for the purposes of the present study, because participants, who are native-speakers of Russian, interpreted idioms from two other languages, which allowed to adjust for the varying level of students' knowledge of English in general and awareness of idioms in particular. The advantage of the paired t-test is that it also makes it possible to calculate the result both including and excluding the outliers. The results proved to be significant in both cases.

\section{Results}

The paired t-test statistical tool revealed a slight imbalance in favour of the Bulgarian idioms, which is statistically significant at p-value equaling 0.0157952 . The observed standardized effect size is medium (0.35) and there are 15 outliers, i.e. participants who came up with an equal or a slightly higher number of English idioms. Table 4 indicates the number of correctly interpreted English and Bulgarian idioms by each of the 50 participants. Table 5 sums up the results of the paired ttest analysis. Fig. 1 is a graphic illustration of the T-Distribution. 
Nataliya A. Lavrova and Elena A. Nikulina. Russian Journal of Linguistics. 2020. T. 24. № 4. C. 831—857

Table 4

The number of correctly interpreted English and Bulgarian idioms by each of the $\mathbf{5 0}$ participants

\begin{tabular}{|c|c|c|}
\hline $\begin{array}{l}\text { Number } \\
\text { of students }\end{array}$ & $\begin{array}{l}\text { Number of correctly interpreted } \\
\text { English idioms }\end{array}$ & $\begin{array}{c}\text { Number of correctly interpreted } \\
\text { Bulgarian idioms }\end{array}$ \\
\hline 1 & 5 & 10 \\
\hline 2 & 5 & 13 \\
\hline 3 & 9 & 9 \\
\hline 4 & 5 & 10 \\
\hline 5 & 16 & 10 \\
\hline 6 & 6 & 7 \\
\hline 7 & 11 & 11 \\
\hline 8 & 6 & 6 \\
\hline 9 & 17 & 17 \\
\hline 10 & 14 & 16 \\
\hline 11 & 6 & 9 \\
\hline 12 & 13 & 2 \\
\hline 13 & 3 & 7 \\
\hline 14 & 4 & 7 \\
\hline 15 & 8 & 10 \\
\hline 16 & 11 & 10 \\
\hline 17 & 5 & 10 \\
\hline 18 & 3 & 10 \\
\hline 19 & 4 & 9 \\
\hline 20 & 4 & 11 \\
\hline 21 & 5 & 10 \\
\hline 22 & 24 & 14 \\
\hline 23 & 25 & 14 \\
\hline 24 & 4 & 7 \\
\hline 25 & 11 & 13 \\
\hline 26 & 9 & 12 \\
\hline 27 & 7 & 7 \\
\hline 28 & 4 & 11 \\
\hline 29 & 8 & 9 \\
\hline 30 & 11 & 16 \\
\hline 31 & 6 & 12 \\
\hline 32 & 7 & 12 \\
\hline 33 & 12 & 15 \\
\hline 34 & 16 & 13 \\
\hline 35 & 15 & 13 \\
\hline 36 & 8 & 15 \\
\hline 37 & 8 & 14 \\
\hline 38 & 13 & 13 \\
\hline 39 & 10 & 10 \\
\hline 40 & 7 & 10 \\
\hline 41 & 7 & 9 \\
\hline 42 & 7 & 11 \\
\hline 43 & 7 & 9 \\
\hline 44 & 6 & 8 \\
\hline 45 & 7 & 10 \\
\hline 46 & 5 & 9 \\
\hline
\end{tabular}




\begin{tabular}{|c|c|c|}
\hline $\begin{array}{c}\text { Number } \\
\text { of students }\end{array}$ & $\begin{array}{c}\text { Number of correctly interpreted } \\
\text { English idioms }\end{array}$ & $\begin{array}{c}\text { Number of correctly interpreted } \\
\text { Bulgarian idioms }\end{array}$ \\
\hline 47 & 9 & 10 \\
\hline 48 & 13 & 5 \\
\hline 49 & 6 & 7 \\
\hline 50 & 11 & 10 \\
\hline
\end{tabular}

Table 5

Results of the paired t-test analysis as applied to the interpretation of Bulgarian and English Idioms

\begin{tabular}{|c|c|c|c|}
\hline Null hypothesis $\left(\mathrm{H}_{0}\right)$ & P-value & The statistics & Effect size \\
\hline $\begin{array}{c}\text { Since } p \text {-value }<\alpha, \\
H_{0} \text { is rejected. } \\
\text { The average of After } \\
\text { minus Before's } \\
\text { population is } \\
\text { considered to be not } \\
\text { equal to the } \mu_{0} . \\
\text { The difference } \\
\text { between the average } \\
\text { of the After minus } \\
\text { Before and } \mu_{0} \text { is big } \\
\text { enough to be } \\
\text { statistically significant. }\end{array}$ & $\begin{array}{c}\mathrm{p} \text {-value equals } \\
0.0157952, \\
(\mathrm{p}(\mathrm{x} \leq \mathrm{t})=0.992102) \text {. } \\
\text { This means that the } \\
\text { chance of type } 1 \text { error } \\
\text { (rejecting a correct } \mathrm{H}_{0} \text { ) } \\
\text { is small: } 0.01580 \\
(1.58 \%) \text {. } \\
\text { The smaller the } \\
\text { p-value the more } \\
\text { it supports } \mathrm{H}_{1} .\end{array}$ & $\begin{array}{c}\text { The test statistic } t \\
\text { equals } 2.500523, \text { is } \\
\text { not in the } 95 \% \text { critical } \\
\text { value accepted range: } \\
{[-2.0096: 2.0096] \text {. }} \\
x=1.58, \text { is not in the } \\
95 \% \text { accepted range: } \\
{[-1.2700: 1.2700] \text {. }}\end{array}$ & $\begin{array}{c}\text { The observed } \\
\text { standardized effect } \\
\text { size is medium }(0.35) \text {. } \\
\text { That indicates that the } \\
\text { magnitude of the } \\
\text { difference between } \\
\text { the average and } \mu_{0} \text { is } \\
\text { medium. }\end{array}$ \\
\hline
\end{tabular}

T Distribution

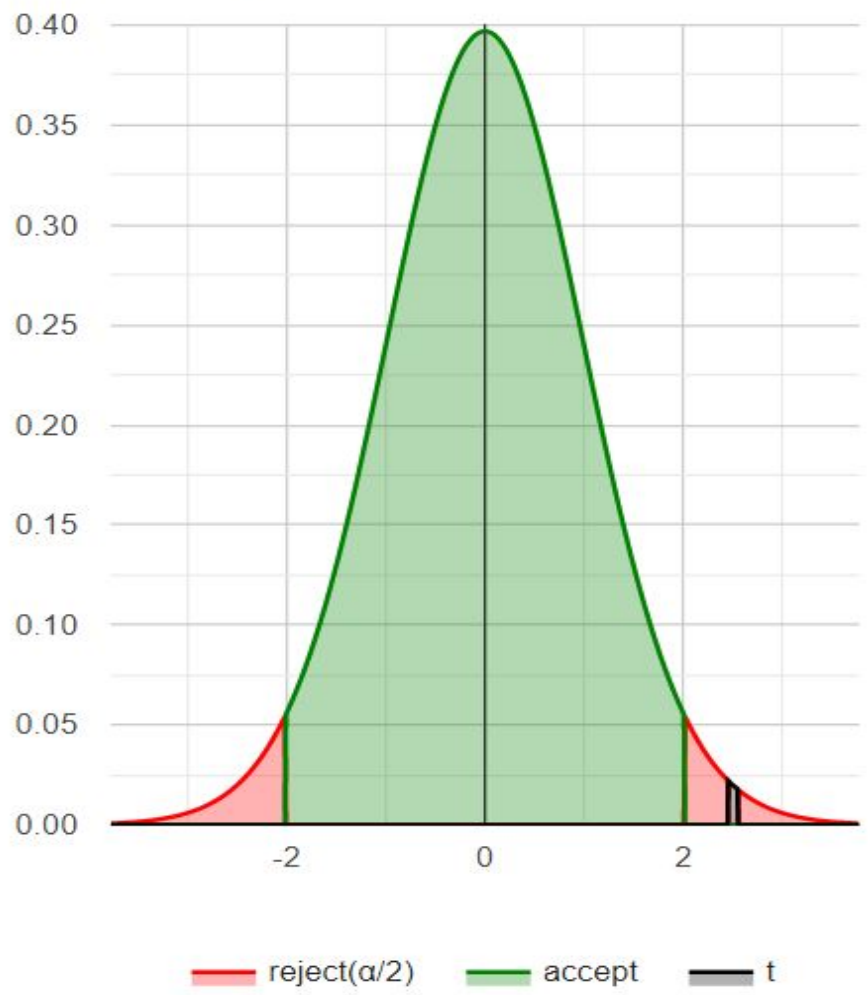

Fig. 1. T-Distribution 


\section{Discussion}

Most of the difficulties in interpretation were caused by idioms containing cultural allusions, such as the proper name Nedd Kelly. Correct interpretation of this idiom and the idiom in Abraham's bosom requires a higher degree of thesaurus activation - background knowledge of the relevant realia, including knowledge of the Bible and the history of English. Although the idiom plain Jane also contains a proper name, its interpretation did not cause much difficulty due to the presence of the first 'give-away' adjective used in its direct, rather than transferred meaning: 'not attractive or pretty enough'. Other idioms that caused interpretative difficulty were damp squib, in jig time and all hands. The first one contains an unusual element as it is rarely used outside this idiom. The expression in jig time contains a noun used as an adjective and is probably falsely associated with the dance type 'jig', which, coupled with the word 'time', results in an opaque expression. Although this attributive use of a noun is quite typical of English, a comparable use is not found in Russian, hence the difficulty which may have been caused by negative interference - extrapolation of internalized syntactic patterns of one's mother-tongue into a foreign language. Finally, the meaning of the idiom all hands is too specific - it refers to the members of a ship's crew due to which this technical meaning in rarely known as refers to a nautical term.

As predicted, the correct interpretation was given to Bulgarian idioms which contain words and structures shared with the Russian language. This pertains to the idioms гръм от ясно небе lit. 'thunder from the clear sky', имам зъб на някого lit. 'to have a tooth on smb.', не вижда по-далече от носа си lit. 'not to see farther than one's nose', which are structurally and semantically isomorphic to Russian idioms. The most interpretative difficulty was caused by those Bulgarian idioms that contain opaque words (typically, borrowings) or the so-called false friends: cf. на краставичар краставици продавам lit. 'to sell cucumbers to a cucumberseller', стъпвам на врата на някого lit. 'to put one's foot on smb.'s neck'.

Idioms seem to be stored in the long-term memory not only thematically or in topically related clusters, but also according to their source of origin and structure. Given this, cross-cultural code-switching is facilitated when speakers aim to produce idioms which are structurally isomorphic, have common origin or are part of the shared cultural heritage, such as the Latin language, the Bible or calques. This pertains to the English idiom to sell like hot cakes adopted through loantranslation into Bulgarian and Russian, and to the proverb All roads lead to Rome adopted by a number of European languages, including Russian (cp. Все дороги ведут в Рим lit. 'All roads lead to Rome') and Bulgarian (ср. Всички пътища водят към Рим lit. 'All roads lead to Rome').

\section{Conclusion}

The results of the research proved the working hypothesis and revealed that it is the degree of etymological proximity and affinity between languages that is a better predictor of correct interpretation of two sets of idioms by native speakers of 
the language closely related to one of the languages involved in the experiment. Although the Russian participants are all fluent speakers of English, their largely implicit cultural cognition makes them potentially more cross-culturally competent when decontextualized set expressions from Bulgarian, rather than English, are given for interpretation. This can partly be explained by a comparable linguistic and axiological prioritization, i.e. a set of values encoded by Russian-Bulgarian idiomatic counterparts rather than Russian-English idioms. This also means that cultural allusions embedded in Russian-Bulgarian idioms are interpreted more efficiently than those encoded by English idioms which in many cases are opaque.

The experiment also partly proves that common cultural conceptualisations of Russians and Bulgarians seem to arise without the participants' prior linguistic or cultural contact, since none of them know Bulgarian or have ever been to Bulgaria. On the other hand, linguistic competence is not in itself a sure predictor of correct interpretation of stable multi-word units. This seems to suggest that a lack of intercultural competence is a factor to reckon with. Putting it differently, a comparable set of intercultural values reflected in language significantly facilitates interpretation of stable multi-word items. Whether the same holds true for single words or, possibly, sentences is a matter of further investigation.

The implications of the research are manifold. The background knowledge of linguistic and cultural information connected with set expressions is likely to facilitate code-switching and to raise communicants' awareness of the extensive international stock of idioms. From the typological and genealogical point of view, the main paradigmatic relations that exist between Bulgarian, Russian and English idioms should be taken into account during cross-cultural communication: interlocutors should be alerted to a rather numerous group of false friends in order to avoid communicative breakdowns and to speed up and facilitate the process of cross-cultural communication.

One of the fascinating areas and desiderata for further research is the systemic investigation of the relations between Russian, Bulgarian and English paremiological units, i.e. proverbs and sayings. Preliminary findings suggest that approximately $15 \%$ of cases idioms and proverbs which descended from one and the same source, such as the Bible or fables, have acquired slightly different connotations in Russian, Bulgarian and English. This definitely proves that language does not remain static or develops in isolation: the people, the nation and the culture, i.e. the proprietors and the bearers of a language, are prone, either willingly or unwittingly, to slightly modify the meanings of linguistic items to suit their communicative needs.

Some of the avenues for further research comprise the following aspects: (1) theoretical and empirical research into the quantifiable correlation between the degree of genealogical proximity of languages and the number of correct interpretations of idioms, (2) study of conditions that stimulate loan-translation and the semantic fields which are more likely to be loan-translated, (3) cross-linguistic typological comparison of the symbolic meaning of numbers in Russian, Bulgarian 
and English idioms. While preliminary findings have shown that number 3 plays an important symbolic role both in Russian and Bulgarian due to the Orthodox Christianity, in Russian other numbers, such as 7, 40, 100 and 1000 seem to play a more prominent role, which could probably be explained by a more pronounced proclivity for exaggeration, a cultural feature of Russian speakers that has been much commented on by Wierzbicka (Wierzbicka 2014).

\section{ACKNOWLEDGEMENT}

The authors wish to express their deepest and immeasurable gratitude to Editor-in-Chief, Prof. Tatiana Larina for her kind attitude, invaluable critical comments and genuine interest in our research. She opened new vistas, alerted us to new research in the field and inspired us to further investigate the fascinating area of comparative and cultural linguistics. For this, we thank her again and again. We also thank the anonymous reviewers for a generous review and the Chief secretary Alexander Ignatenko for proof-reading and editing the manuscript.

Участие авторов: Лаврова Н.А. - концепция, дизайн исследования и написание текста. Никулина Е.А. - анализ полученных данных, выводы, перспективы исследования, написание текста.

(C) Nataliya Lavrova and Elena Nikulina, 2020
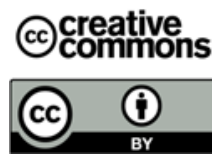

This work is licensed under a Creative Commons Attribution 4.0 International License https://creativecommons.org/licenses/by/4.0/

\section{REFERENCES}

Antipova, Mariya A. \& Yana A. Matveeva. 2014. The international conference "Russian linguistics: A history and the present”. Slověne 3 (1). 221-223. DOI: 10.31168/2305-6754. 2014.3.1.9

Baranov, Anatoli N. \& Dmitry Dobrovol'skij. 2014. Osnovi Frazeologii. Moscow, Russia: Flinta. [The basics of phraseology].

Bilá, Magdaléna \& Svetlana Ivanova. 2020. Language, culture and ideology in discursive practices. Russian Journal of Linguistics 24 (2). 219-252. DOI: 10.22363/2687-00882020-24-2-219-252.

Chrissou, Marios. 2018. Interlinguale Faktoren für die Erfassung des Lernschwierigkeitsgrads von Phrasemen des Deutschen unter besonderer Berücksichtigung von DaF-Lernenden mit Griechisch als Muttersprache. Yearbook of Phraseology 9 (1). 111-136. DOI: 10.1515/phras-2018-0007. [Interlinguistic factors in the assessment of difficulty of learning German idioms by students of German as a foreign language with emphasis on native speakers of Greek].

Columbus, Georgie. 2013. In support of multiword unit classifications: Corpus and human rating data validate phraseological classifications of three different multiword unit types. Yearbook of Phraseology 4 (1). 23-44. DOI: https://doi.org/10.1515/phras-2013-0003.

Cranmer, Robin. 2017. Intercultural communicative competence - a further challenge. Russian Journal of Linguistics 21 (4). 870-884. DOI: 10.22363/2312-9182-2017-21-4-870-884. 
Deignan, Alice. 2005. Metaphor and Corpus Linguistics. Amsterdam-Philadelphia, The Netherlands, US: John Benjamins.

Dobrikova, Mária. 2008. On phraseological conception in the Slovak and Bulgarian languages. Slavica Slovaca 43 (1). 52-63.

Fiedler, Sabine. 2007. English Phraseology. Leipzig: Gunter Narr Verlag Tübingen.

Floria, Boris N. 2017. The Slavic world and its destiny in the earliest epoch of its history according to the first redaction of the Chronicle by Marcin Kromer. Slovéne 6 (1). 381-392.

Holandi, Rayna. 2009. Semantic relations in the comparative phraseological units in English and Bulgarian. Eğitim Fakültesi Dergisi XXII. URL: https://dergipark.org.tr/tr/download/ article-file/153388. (Accessed on 15 June, 2020).

Ivanova, Elena Yu. 2019. Contrastive analysis of Bulgarian and Russian syntax peculiarities. Slověne 8 (1). 554-563. DOI: 10.31168/2305-6754.2019.8.1.22.

Keipert, Helmut. 2017. Conceptions of Church Slavonic. Slověne 6(1). 8-75. DOI: http://dx.doi.org/10.31168/2305-6754.2017.6.1.1.

Kuiper, Koenraad. 2013. Psycholinguistics, neurolinguistics and phraseology. Yearbook of Phraseology 4 (1). 1-2. DOI: https://doi.org/10.1515/phras-2013-0001.

Mitkovska Liljana, Eleni Bužarovska \& Elena Ju. Ivanova. 2017. Apprehensive-epistemic daconstructions in Balkan Slavic. Slověne 6 (2). 57-83.

Mokienko, Valerij M. 2017. Psycholinguistic aspects of Slavic phraseology: "Slavofraz-2016". Slověne 6 (1). 576-587.

Nelyubova, Natalia, Victoria Hiltbrunner \& Victor Ershov. 2019. The reflection of the hierarchy of values in the proverbial fund of the Russian and French languages. Russian Journal of Linguistics 23(1). 223-243. DOI: 10.22363/2312-9182-2019-I-223-243.

Podtergera, Irina A. 2015. What is language history? Slověne 4(1). 394-455. DOI: http://dx.doi.org/10.31168/2305-6754.2015.4.1.26.

Polyvyannyy, Dmitry I. 2016. Bulgarian polemical literature in the confessional strife between Rome and Constantinople. Slověne 5 (2). 370-376. DOI: http://dx.doi.org/10.31168/23056754.2016.5.2.10.

Saenko, Mikhail N. 2017. History of the semantics of the Proto-Slavic lexemes *edinŭ and *samŭ. Slověne 6 (1). 76-94.

Sharifian, Farzad. 2017. Cultural Linguistics. Amsterdam: Philadelphia: John Benjamins Publishing House, 2017.

Solano, Ramón M. \& Mária Kolářová. 2015. Phraseological loan translations in Bulgarian and in French: A cross-linguistic and cross-cultural study. Contrastive Linguistics 3. 9-31. DOI: https://hal.archives-ouvertes.fr/hal-01646142.

Sosnowski, Wojciech P., Diana Blagoeva \& Roman Tymoshuk. 2018. New Bulgarian, Polish, and Ukrainian phraseology and language corpora. Cognitive Studies. Études Cognitives 18. 1-13. DOI: https://doi.org/10.11649/cs.

Szerszunowicz, Joanna. 2015. Periodic growth of phrasemes from a cross-linguistic perspective: Polish phraseology after the political transformation of 1989. Yearbook of Phraseology 6 (1). 103-124. DOI: https://doi.org/10.1515/phras-2015-0007.

Todorova, Bilyana B. 2019. Bulgarian-English code-switching in Internet forum communication: The BG-mamma case. Open Linguistics 5 (1). 121-135. DOI: https://doi.org/ 10.1515/opli-2019-0008.

Todorova, Maria. 2015. On the automatic recognition of Bulgarian verb idioms. Paisievi Cheteniya. Plovdiv, Bulgaria. URL: https://www.researchgate.net/publication/ 305328336_ON_THE_AUTOMATIC_RECOGNITION_OF_BULGARIAN_VERB_ID IOMS (Accessed on $1 \overline{5}$ June, 2020). 
Urmanchieva, Anna Yu. \& Vladimir A. Plungian. 2017. The perfect in Old Church Slavonic: Was it resultative? Slověne 6 (2). 13-56. DOI: 10.31168/2305-6754.2017.6.2.1.

Vashcheva, Irina Yu. \& Dmitry A. Koryakov. 2018. Medieval Bulgaria in the context of political imagology. Slověne 7 (2). 527-537. DOI: 10.31168/2305-6754.2018.7.2.21.

Vinogradov, Andrey Yu. \& Anastasia S. Dobychina. 2018. "Erinyes and Maenads". Who stood at the cradle of the new Bulgarian community in 1185-1186? Sloverne 7 (1). 41-54. DOI: 10.31168/2305-6754.2018.7.1.3.

Waugh, Daniel C. 2019. The Great Turkes defiance revisited. Slověne 8 (1). 162-187. DOI: 10.31168/2305-6754.2019.8.1.6.

Wierzbicka, Anna. 2014. Imprisoned in English: The Hazards of English as a Default Language. Oxford: Oxford University Press.

Zholobov, Oleg F. 2016. Notes on the word form je 'is' in Old Russian and Old Church Slavonic literature. Slověne 5 (1). 114-125.

\section{Dictionaries and other sources}

Ankova-Nicheva, Keti. 1993. Nov Fraseologichen Rechnik na Bylgarskija Ezik. Sophia, Bulgaria: Izdatel'stvo universiteta Sv. Kliment Ochridskij. [New phraseological dictionary of Bulgarian].

Brown, Keith \& Sarah Ogilvie. 2009. Concise Encyclopedia of Languages of the World. Oxford, UK: Elsevier Ltd.

Gurevich, Valery V. \& Jeanna A. Dozorets. 1988. Kratkij Russko-anglijskij Fraseologicheskij Slovar' Moscow, Russia: Russkij Jazik. [A short Russian-English phraseological dictionary].

Kotova, Nandezhda \& Miroslav Janakijev. 2001. Grammatica Bolgarskogo Jazika dl'a Vladejusschich Russkim Jazikom Moscow, Russia: Izdatel'stvo Moskovskogo Universiteta. [Grammar of Bulgarian for those who know Russian].

Leafgren, John. 2011. A Concise Bulgarian Grammar. URL: http://www.seelrc.org:8080/ grammar/pdf/stand_alone_bulgarian.pdf. (Accessed on 15 June, 2020.)

Maslov, Yuri S. 1981. Grammatica Bolgarskogo Jazika. Moscow, Russia: Visschaja schkola. [Grammar of Bulgarian].

The Oxford Dictionary of Idioms. 2004. Oxford: Oxford University Press.

Pashova, Marinella. 2005. Bulgarian 4 Brits. Southampton, UK: Probmags Publishing.

Sabeva, Radost \& Zhana Zagorova. 2015. Speak Bulgarian Like a Native. Bulgarian Idioms in Context. Sophia: CreateSpace Independent Publishing Platform.

Stepanov, Yuri S. 2016. Osnovi Obschego Yazikoznanija. Moscow, Russia: Lenand. [Introduction to general linguistics].

Article history:

Received: 26 July 2020

Revised: 15 October 2020

Accepted: 17 October 2020

История статьи:

Дата поступления в редакцию: 26 июля 2020

Дата принятия к печати: 17 октября 2020 


\section{Bionotes:}

Nataliya LAVROVA, PhD (Advanced Doctorate), Associate Professor, Department of English Phonetics and Lexicology, Institute of Foreign Languages, Moscow Pedagogical State University, Moscow, Russia. Research interests include neologisms, cognitive metaphor, linguistic contactology, areal typology.

\section{Contact information:}

e-mail: na.lavrova@mpgu.su

ORCID ID: 0000-0002-6403-781X

Elena NIKULINA, PhD (Advanced Doctorate), Professor, Head of Department of English Phonetics and Lexicology, Institute of Foreign Languages, Moscow Pedagogical State University, Moscow, Russia. Research interests include English terminology and terminography, phraseology, discourse and cognitive linguistics.

\section{Contact information:}

e-mail: ea.nikulina@mpgu.su

ORCID ID: 0000-0002-1269-8720

\section{Сведения об авторах:}

Наталия Александровна ЛАВРОВА - доктор филологических наук, доцент, профессор кафедры фонетики и лексики английского языка, ФГБОУ ВО «Московский педагогический государственный университет», Москва, Россия. Научные интересы: неологизмы, когнитивная метафора, лингвистическая контактология, ареальная типология.

\section{Контактная информация:}

e-mail:na.lavrova@mpgu.su

ORCID ID: 0000-0002-6403-781X

Елена Александровна НИКУЛИНА - доктор филологических наук, профессор, заведующий кафедрой фонетики и лексики английского языка, ФГБОУ ВО «Московский педагогический государственный университет». Научные интересы: лексикология и лексикография английского языка, терминология английского языка, терминография, фразеология и фразеография, проблемы дискурса, когнитивная лингвистика.

\section{Контактная информация:}

e-mail: ea.nikulina@mpgu.su

ORCID ID: 0000-0002-1269-8720 